\title{
State-of-the-art of boar sperm preservation in liquid and frozen state
}

\author{
Marc Yeste ${ }^{1}$ \\ Biotechnology of Animal and Human Reproduction (TechnoSperm), Department of Biology, Institute of Food and Agricultural \\ Technology, University of Girona, Girona, Spain.
}

\begin{abstract}
Pig breeding is mainly conducted through Artificial Insemination (AI) in Western and developing countries. Apart from requiring specific catheters and trained staff, preserving boar semen in proper conditions is needed to ensure high reproductive performances. Although, at present, boar sperm may be preserved in liquid $\left(15-17^{\circ} \mathrm{C}\right)$ or frozen states, more than $95 \%$ of AIs are conducted using liquid semen. The present work reviews the state-the-art of these two preservation technologies. Thus, the composition and types of extenders for liquid-stored semen are discussed, together with the specific requirements for boar sperm, which are stored at $15-17^{\circ} \mathrm{C}$. Commercial extenders for liquid semen are compared and the effects of storage on sperm quality are also summarised. In the second part of the manuscript, the main features of boar sperm cryopreservation are described and reference to cryodamage is also made. These cryoinjuries mainly affect sperm motility, membrane permeability and chromatin integrity. Furthermore, the individual variability in the sperm resilience to withstand cryopreservation procedures is reviewed and a brief summary about freezability markers is also included. Final sections briefly discuss the improvement of freezing extenders with additives, such as seminal plasma and antioxidants, and highlight the relevance of using a proper AI technique to avoid dramatic drops in reproductive performance.
\end{abstract}

Keywords: boar semen, cryopreservation, liquid storage, preservation

\section{Introduction}

Pig breeding in Western and some developing countries is carried through Artificial Insemination (AI). This technique offers several advantages, such as the use of the genetic potential of the best boars with a large number of sows. In addition, not only does AI make genetic improvement easier, but reproductive performance is higher than that obtained with natural mating. Although the first AI protocols in swine were performed at the beginning of the XX century, it was not until the eighties when insemination protocols were standardised and AI started to become commercially generalised (Johnson et al., 2000; Rodríguez-Gil and Estrada, 2013).

Apart from requiring specific catheters for the type of AI that is to be performed, AI may be conducted with liquid/extended or frozen-thawed semen. In both cases, it is important to use the adequate media for maintaining the sperm in adequate conditions. This means that the medium and temperature at which sperm are stored are critical for preserving their quality and fertilizing ability. Given the relevance of AI in swine and the crucial role of sperm preservation when AI is used, the current work aims at reviewing the most crucial aspects for the conservation of boar semen in liquid and frozen states.

\section{Preservation of boar semen in liquid storage at $15-17^{\circ} \mathrm{C}$}

In addition to the high relevance of AI for pig breeding, it is worth noting that most AIs (99\%) are performed using extended semen (Johnson et al., 2000). Extended semen usually consists of seminal doses of $50-100 \mathrm{ml}$ (depending on the type of AI that is to be performed) and a concentration of 1-3 billion sperm per dose. Seminal doses result from the collection of ejaculate rich-fractions, further dilution with an extender and split of diluted semen in doses with the required volume and concentration. Such an extender or diluent is defined as the aqueous solution that allows increasing the volume of the ejaculate up to the required amount, contributes to reduce the sperm metabolic activity, preserves sperm function and maintains a suitable fertility level. Apart from the composition of the extender, the other crucial element to maintain the sperm metabolism at low level is the temperature of storage (Gadea, 2003; Estienne et al., 2007). These two elements will be discussed in further detail in the next paragraphs. On the other hand, as seminal doses are packed in plastic recipients, their composition is also critical. In effect, the presence of toxic compounds may have a strong impact upon reproductive performance (i.e. reduced fertility rates and litter sizes) without exhibiting a detrimental effect on routine sperm quality parameters (Nerin et al., 2014).

\section{Composition of the extender}

In order to carry out its function, the extender must provide the nutrients needed to maintain the sperm metabolism (monosaccharides such as glucose and fructose), protect cells from cold shock (bovine serum albumin, BSA), control the $\mathrm{pH}$ with buffers (Bicarbonate, Tris, HEPES) and the osmotic pressure ( $\mathrm{NaCl}, \mathrm{KCl}$, sodium citrate), and inhibit microbiological growth (with antibiotics such as kanamycin or gentamycin; Estienne et al., 2007).

\section{Nutrients}

Spermatozoa produce the energy required to 
maintain their metabolism and allow their intrinsic motility, principally through glycolytic pathways (Rodríguez-Gil, 2013). Therefore, any extender must contain an energy source, which is often glucose, as other sources such as galactose, ribose and threhalose have been reported to give worse results (Gadea, 2003). In addition to this, Medrano et al. (2005) evaluated the suitability of different combinations of sugars (glucose) and non-sugars energy substrates (citrate and lactate) during a 7-day period of storage at $17^{\circ} \mathrm{C}$. Interestingly, these authors observed that boar sperm quality was better preserved in a medium containing $150 \mathrm{mM}$ glucose and $25 \mathrm{mM}$ sodium lactate than standard BTS (205 mM glucose and $20 \mathrm{mM}$ sodium citrate).

On the other hand, dilution of sperm involves a reduction in the levels of certain ions and molecules that are present in the seminal plasma and play a key role in sperm viability, such as potassium ion $\left(\mathrm{K}^{+}\right)$and seminal plasma proteins (Harrison et al., 1978). Since the reduction of these substances may alter sperm function and survival, a proper formulation of the extender should also take this aspect into account. Thus, proteins such as BSA are included in the extenders as they maintain sperm motility, membrane integrity and reproductive performance (Waberski et al., 1994; Zhang et al., 2015).

\section{Regulation of $\mathrm{pH}$}

Immediately after ejaculation, semen $\mathrm{pH}$ is approximately $7.4 \pm 0.2$. When $\mathrm{pH}$ decreases, there is a concomitant reduction in the energetic metabolism and sperm motility. As sperm glycolytic metabolism reduces the intracellular $\mathrm{pH}$, and this ultimately decreases the cell metabolism, the presence of buffers in the extender is required to control $\mathrm{pH}$ variations.

Previous research evaluated the suitability of different buffers, differentiating between simple systems, such as bicarbonate or sodium citrate, which both have only a limited ability to buffer $\mathrm{pH}$, and more complex systems such as TES, HEPES, Mops or Tris, that are able to regulate $\mathrm{pH}$ within a wider range, even when changes in temperature occur (Gadea, 2003). Notwithstanding, while replacing bicarbonate by HEPES has been found to reduce the percentages of sperm exhibiting an exocytosed acrosome when exposed to calcium ionophore A23187, it also decreases sperm motility, as bicarbonate activates sperm motility (Murase et al., 2010). This indicates that it is important to achieve a proper balance between buffer systems.

The $\mathrm{pH}$ of commercial extenders usually ranges from 6.8 to 7.2 units, but two considerations must be taken into account. First, $\mathrm{pH}$ is not stabilised until 90 min after dilution of the powder in water; and second, different extenders present different patterns of $\mathrm{pH}$ values over time (Newth and Levis, 1999). For these reasons, care is needed when preparing the extender in order to avoid additional problems for sperm preservation. It is also worth noting that boar semen should be kept out of contact with air, as Vyt et al. (2007) demonstrated that high air volume is related to an increase in the $\mathrm{pH}$ and to a decrease in the proportions of motile spermatozoa. Therefore, it is important to decrease the air volume in the recipient as much as possible when packing seminal doses.

\section{Osmotic pressure}

Osmotic pressure varies between commercial extenders for liquid semen, ranging from 240 to 380 $\mathrm{mOsm} \cdot \mathrm{Kg}^{-1}$. While boar sperm have been found to be able to tolerate osmolalities ranging between 250 and $390 \mathrm{mOsm} \cdot \mathrm{Kg}^{-1}$, isotonic $\left(300 \mathrm{mOsm} \cdot \mathrm{Kg}^{-1}\right)$ or slightly hypertonic extenders have been reported as the best diluents for maintaining sperm quality (Schilling and Vengust, 1986; Fraser et al., 2001). In order to regulate osmotic pressure, halide salts such as sodium chloride $(\mathrm{NaCl})$ and potassium chloride $(\mathrm{KCl})$ are those most often used in semen extenders.

\section{Antibiotics}

Apart from the negative impact on the female, bacterial contamination results in different alterations on sperm integrity and function, including a decrease in sperm motility and viability, sperm agglutination, degenerative acrosome exocytosis, and changes in the pH (Althouse et al., 2000; Bussalleu et al., 2011; Sepúlveda et al., 2013, 2014, 2016; Prieto-Martínez et al., 2014). As a result, there is a reduction in the time that seminal doses can be stored at $15-17^{\circ} \mathrm{C}$. Therefore, antibiotics are added to avoid bacterial growth in the extender, as nutrients such as glucose and the storage temperature $\left(15-18^{\circ} \mathrm{C}\right)$ of refrigerated semen allow the development of gram-negative bacteria, such as Escherichia coli, Salmonella sp. and Pseudomonas sp.

The first studies about the effects of antibiotics on boar semen were conducted at the start of the 1980s. Sone et al. (1982) compared the ability of nine antibiotics to control the growth of eleven bacterial genera commonly present in boar semen and found that dibekacin, amikacin and gentamicin were the most effective with the lowest minimum inhibitory concentrations (Sone et al., 1982). Other works have aimed at elucidating how the presence of antibiotics in semen extenders affects the quality and fertilizing ability of boar sperm. A recent study by Bryła and Trzcińska (2015) combined gentamicin, one of the most common antibiotics used in boar semen, with others such as florfenicol and polymyxin $\mathrm{B}$, for a period of 10 days and found that the combination of $100 \mu \mathrm{g} / \mathrm{ml}$ gentamicin and $100 \mu \mathrm{g} / \mathrm{ml}$ florfenicol was the one that yielded the best results.

\section{Temperature}

Mammalian sperm especially that from boars are very sensitive to cold-shock, due to their physicochemical characteristics (Pursel et al., 1973). Specifically, the lipid composition of the plasma membrane explains this phenomenon, as the susceptibility of sperm to cold shock is related to low cholesterol content and high ratio of unsaturated:saturated fatty acids in phospholipids.

The lateral movements of plasma membrane phospholipids are reduced when the temperature 
decreases to $5^{\circ} \mathrm{C}$ and below, causing a lipid-phase separation and involving irreversible changes to membrane proteins. The destabilization of the plasma membrane induces premature capacitation-like changes, compromises the sperm viability and reduces the fertilizing ability (Buhr et al., 1989; White, 1993; Harrison, 1997). In addition, cold-shock by rapid cooling to near freezing point decreases sperm motility and damages acrosome and plasma membranes. The fact that boar spermatozoa present high content of unsaturated fatty acids also makes them susceptible to peroxidation of lipid membranes. Finally, if extracellular $\mathrm{Ca}^{2+}$ levels are high, there may be 'calcium intoxication' during coldshock, as decreasing the temperature of the environment increases calcium uptake by sperm. All these aspects have to be taken into account when preserving boar semen in liquid and frozen storage (White, 1993; Vadnais and Althouse, 2011).

The aforementioned susceptibility of boar sperm to cold-shock makes necessary to keep sperm samples at temperatures ranging between 15 and $20^{\circ} \mathrm{C}$, as a more extreme reduction in storage temperature may strongly compromise the viability of seminal doses (Althouse et al., 1998; Zou and Yang, 2000; Huo et al., 2002a; Kommisrud et al., 2002; Purdy et al., 2010). However, storage at these temperatures puts a limit on the length of time sperm samples can be kept, because cell metabolism is not sufficiently reduced and the control of microbiological contamination is not as effective as it would be at lower temperatures, such as $5^{\circ} \mathrm{C}$. For this reason, and as discussed in the previous section, the presence of antibiotics is crucial to keep bacterial growth under control.

The exact temperature of storage is critical and separate extenders exhibit different properties according to the temperature of storage. Indeed, Schmid et al. (2013a) showed that Androstar Plus was able to keep sperm better than BTS, when semen was stored for four days at hypothermic conditions $\left(5\right.$ and $\left.10^{\circ} \mathrm{C}\right)$. These differences were not only observed in sperm motility and membrane integrity but also in the sperm response to capacitation medium. In addition, these authors also found that after conducting an AI trial involving 778 sows with semen that was kept for two days, the reproductive performance of sperm stored in Androstar Plus at $10^{\circ} \mathrm{C}$ did not differ from that preserved in BTS at $17^{\circ} \mathrm{C}$.

The decrease of the temperature of semen may be performed in one or two steps. However, in a study conducted by López Rodríguez et al. (2012), ejaculates were initially diluted $1: 1$ at $30^{\circ} \mathrm{C}$ and then re-diluted to a final concentration of $3 \times 10^{7} \mathrm{spermatozoa} \cdot \mathrm{ml}^{-1}$ either at 29.3 or at $22.7^{\circ} \mathrm{C}$. Semen was further stored, transported at $17^{\circ} \mathrm{C}$ and evaluated, but there were no differences in the quality of liquid-stored semen between the two temperatures at the second dilution-step (López Rodríguez et al., 2012).

\section{Long- and short-term refrigeration extenders}

Refrigeration extenders are divided into two groups based on the period of storage. Accordingly, there are short-term extenders, able to preserve sperm for up to three days (Johnson et al., 1982); and longterm extenders, for keeping the semen for more than four days (Dubé et al., 2004; Vyt et al., 2004; Haugan et al., 2007). As $85 \%$ of the AIs conducted with extended semen are performed within the first two days after semen collection, the most rational decision in some cases may be the use of a short-term extender, which is less expensive and may be quite effective in preserving sperm quality.

As there are different commercial diluents available, separate studies have compared these media, including direct comparisons between short- and longterm diluents. An early comparative study between two short-term extenders (Kiev and Beltsville Thawing Solution, BTS) concluded that Kiev yielded better reproductive performance than BTS (Johnson et al., 1982). However, another work, which compared the preservation abilities of short- and long-term extenders (BTS, Androhep, Kiev and Zorlesco) at $17^{\circ} \mathrm{C}$ for a $15-$ day period, found that Androhep and Zorlesco were the most suitable, ranking those media as follows: Androhep, Zorlesco, BTS and Kiev (Huo et al., 2002b). Therefore, in the study by Huo et al. (2002b), BTS reported better results than Kiev.

Dubé et al. (2004) conducted a study that compared a long-term (Androhep Plus) and a short-term extender (BTS) for a storage period of 12-days. Whereas no significant differences between extenders were observed for sperm viability, Androhep Plus presented significantly higher percentages of progressively motile spermatozoa. In addition, capacitation markers, such as chlortetracycline (CTC) and tyrosine-phosphorylation patterns of sperm proteins showed that capacitation-like changes occurred earlier in BTS than in Androhep Plus and these differences were already apparent at day 2 .

Another study compared the sperm quality of semen stored in BTS for three days with semen stored for five days in three long-term extenders and found that membrane and acrosome integrities of sperm stored for five days in X-cell and Mulberry III were similar to those of sperm stored in BTS for three days (Waterhouse et al., 2004). This matches with the study of Vyt et al. (2004) which compared five different commercial extenders: three long-term (Mulberry III, Androhep and Acromax) and two short-term (Kobidil+ and BTS) following sperm storage for 7 days and found that Mulberry III was the one that better preserved the sperm motility. Membrane integrity did not significantly differ between extenders, even if the two short-term extenders supposedly preserved the sperm function over three days. Also, the increase in the $\mathrm{pH}$ over storage was lesser in samples stored in Mulberry III.

The work conducted by Estienne et al. (2007), compared the abilities of nine extenders (BTS, MerckIII, Androhep-lite, Sperm Aid, MR-A, Modena, X-Cell, VSP, and Vital) to preserve boar sperm motility for 7 days at $18^{\circ} \mathrm{C}$. They found that total sperm motility was better preserved by X-Cell, whereas progressive sperm motility and VAP were better preserved by Modena extender. In addition, VSL and LIN were better preserved in Androhep-lite. In spite of these differences, all the extenders except Sperm Aid presented a high 
capability to preserve sperm motility during the 7-day period of storage (Estienne et al., 2007).

The study performed by De Ambrogi et al. (2006) compared a short-term extender (BTS+; IMV technologies) with two long-term extenders (MR-A and $\mathrm{X}$-Cell) during storage at $17^{\circ} \mathrm{C}$ for $96 \mathrm{~h}$ in their abilities to preserve sperm motility and viability, and chromatin integrity. The most interesting result of that study was that there were no changes in chromatin integrity at the end of the 4-day period. As this is a short period of time for long-term extenders, more research involving longer storage periods is warranted. Yet, one should note that basal levels of chromatin fragmentation in boar sperm are usually low (De Ambrogi et al., 2006).

Despite the fact that long-term extenders are widely used for sperm storage, AI with refrigerated semen is performed within the first three days of collection. In our lab, we compared a short- (BTS) and a long-term (Duragen) extenders and found that while the long-term extender preserved better the sperm quality than the short-term one, no differences between the two extenders were observed when AI was performed in the first two days after collection (Pinart et al., 2015a). This indicates that the use of long-term extenders is not required when $\mathrm{AI}$ is performed within the first two days post-collection.

In another comparative study involving four commercial extenders and a homemade medium, called swine fertilization medium (SFM) and intended to biotechnological applications, such as sperm-mediated gene transfer, Fantinati et al. (2009) found that such an extender presented a high capacity of preserving boar sperm for 15 days at $16.5^{\circ} \mathrm{C}$. This medium (which contained $11.25 \mathrm{~g}$ glucose, $10 \mathrm{~g}$ sodium citrate- $2 \mathrm{H}_{2} \mathrm{O}$, $4.7 \mathrm{~g}$ ethylene diamine tetra-acetic acid (EDTA) $-2 \mathrm{H}_{2} \mathrm{O}$, 3.25 g citric acid- $\mathrm{H}_{2} \mathrm{O}, 6.5 \mathrm{~g}$ Trizma, 6 g BSA and $1 \mathrm{~g}$ ampicillin sodium salt per liter; $\mathrm{pH}$ adjusted to 6.8 ) yielded similar results to other commercial, long-term extenders, such as Androhep Enduraguard (long-term), BTS (short-term), MerkIII (short-term) and Androstar (BSA-free, long-term). Although the composition of commercial extenders may not be completely revealed due to intellectual property reasons, sodium bicarbonate, which as aforementioned is a capacitating agent, was not present in SFM and was replaced by Trizma as buffer. In addition, SFM contained high levels of BSA, which preserves sperm function and viability, and EDTA which is a chelating agent that sequesters divalent metal ions, such as $\mathrm{Ca}^{2+}$. As $\mathrm{Ca}^{2+}$ influx plays a crucial role in sperm capacitation, the presence of EDTA prevents premature sperm capacitation.

Finally, while most of the works have compared the abilities of extenders to preserve sperm membrane integrity and motility during short- and longterm storage, only a few have compared their impact upon reproductive performance. Haugan et al. (2007) compared the reproductive performance of semen preserved for 4-5 days prior to AI with semen stored in BTS for 2-3 days. No significant differences were found when these two extenders were compared, and X-cell yielded good reproductive performances when used after 4-5 days. In a study that compared Androhep and
X-Cell extenders and storage for 2, 3, 4, 5 and 6 days prior to use, Kutser and Althouse (1999) found that both extenders did not differ in terms of sperm aging and farrowing rates when semen was stored for 4 or 5 days. However, farrowing rates in gilts inseminated with Androhep were lower than those obtained with X-Cell when semen was stored for 6 days. In addition, whereas litter sizes did not differ between extenders at days 2 and 3, gilts inseminated with semen extended with Androhep showed lower litter size after storage for 4-5 days. The study recommended the use of Androhep extender within the first three days of collection and that of X-Cell if AI was to be performed after six days postcollection (Kuster and Althouse, 1999).

In summary, there is a consensus in that commercial long-term extenders preserve the sperm quality and fertilizing ability better than the short-term ones when the period of storage is longer than three days.

\section{Effects of liquid-storage on sperm quality}

Although extenders differ in the period in which they are able to keep the semen intact, storage affects sperm quality. Therefore, an important issue that deserves to be mentioned here is that apparent good preservation of boar semen in liquid storage may not correspond to good reproductive performance when this semen is used for AI. A main concern is the fact that conventional spermiogram parameters do not reflect the decline in the fertilizing ability during liquid storage at $15-17^{\circ} \mathrm{C}$. For this reason, different studies have tried to investigate whether the response of liquid-stored sperm to bicarbonate, the capacitation effector (Harrison, 1997; Yeste, 2013), varies over storage for separate time periods 12, 24, 72, 120, and $168 \mathrm{~h}$ (Henning et al., 2012). At each of these relevant time points, and even though the sperm quality evaluated through motility and membrane integrity was good, the response of sperm to bicarbonate after density gradient washing evaluated through intracellular calcium levels revealed that there was a binary response. In effect, while intact sperm were less able to respond to the presence of bicarbonate, the other sperm subpopulation was more unstable (Henning et al., 2012). That being said, another study conducted by the same research group and in which semen was stored in liquid storage at $17^{\circ} \mathrm{C}$ for three days showed that despite the percentage of motile spermatozoa in response to bicarbonate decreasing over storage, the percentage of fast-linear sperm subpopulation remained unchanged. Again, this supports the idea of a binary response as there is loss of motility after three days of storage but the percentage of fast-linear spermatozoa does not change (Henning et al., 2014). Related to this, Schmid et al. (2013b) observed that the sperm response to capacitation stimuli in hypothermic conditions was related to the length and temperature of storage.

Semen storage in BTS at $15^{\circ} \mathrm{C}$ for seven days has also been reported to increase oxidative stress (measured as photon emission), which is concomitant with a reduction in the intracellular ATP levels and sperm motility (Gogol et al., 2009). In spite of this, it is 
worth mentioning that basal reactive oxygen species (ROS) and lipid peroxidation have been found to be low in viable, fresh and frozen-thawed semen, with levels being $\leq 4 \%$ (Guthrie et al., 2008). Liquid storage for three or more days has also been found to induce changes in the structure of sperm subpopulations based upon the status of plasma membrane (Pérez-Llano et al., 2009), increase chromatin fragmentation (Boe-Hansen et al., 2005), and decrease acrosin activity (Pinart et al., 2013) and penetration rates following IVF (Suzuki et al., 2005).

Finally, handling seminal doses may also affect sperm quality over liquid-storage. Indeed, Schulze et al. (2015) found that rotation of seminal doses impairs sperm quality (membrane integrity and motility) and alkalanizes the $\mathrm{pH}$ of BTS-extender, that is why rotation of doses is not recommended prior to AI.

\section{Improvement of refrigeration extenders}

A significant number of studies have tried to improve semen extenders by supplementation with specific additives. The nature and functions of these additives is very wide, as too are the results of that addition. For example, the addition of hyaluronic acid to BTS has been reported to delay premature capacitation induced by short-term storage at $15^{\circ} \mathrm{C}$ (Yeste et al., 2008).

Another substance that has been tested is BSA. Zhang et al. (2015) supplemented Modena extender with different concentrations of BSA ( 1 to $6 \mathrm{~g} / \mathrm{L})$ and found that the addition of 3-5 g/L increased sperm motility and plasma membrane integrity and decreased malondialdehyde (MDA) levels during liquid storage. The best effect was obtained when $4 \mathrm{~g} / \mathrm{L}$ was added, as that supplementation extended the sperm survival up to 7.5 days. These results reveal that this protein is a main component of long-term extenders.

Reduced glutathione has also been tested as an additive in liquid-storage extenders. In a study performed by Zhang et al. (2016), this antioxidant was reported to increase the sperm motility and membrane integrity and decrease MDA levels of boar semen diluted in Modena extender and stored at $17^{\circ} \mathrm{C}$, the optimal concentration being $1 \mathrm{mM}$.

The effects of adding $10 \mathrm{ng} / \mathrm{ml}$ and $100 \mathrm{ng} / \mathrm{ml}$ indole-3-acetic acid (IAA, plant auxin) on the ability of BTS to preserve sperm function and survival at $15^{\circ} \mathrm{C}$ for 13 days were tested by Toniolli et al. (1996). Whereas they found no effect on sperm motility, they observed an increase in the proportion of viable sperm exhibiting an intact acrosome at the end of the storing period when $10 \mathrm{ng} / \mathrm{ml}$ IAA was present.

The effects of supplementing the liquid-storage extender with melatonin $(1 \mu \mathrm{M})$, which has antioxidant properties, are less clear as it increases the percentages of viable spermatozoa with an intact acrosome but reduces the proportions of progressively motile spermatozoa after seven days of storage at $17^{\circ} \mathrm{C}$. These results do not encourage the use of melatonin in longterm storage (Martín-Hidalgo et al., 2011).

Polymyxin B is known to neutralise the activity of lipopolysaccharide (LPS), which is released by gram negative bacteria and negatively affects sperm quality. Okazaki et al. (2010) found that adding the semen extender with $100 \mu \mathrm{g} / \mathrm{ml}$ Polymyxin B combined with penicillin $\mathrm{G}$ increased the sperm motility after ten days of liquid storage. In addition, the presence of Polymyxin $\mathrm{B}$ in that extender also resulted in an increase of farrowing rates (Okazaki et al., 2010).

Finally, some other substances have been tested when added after storage as it is the case of relaxin. Following incubation of stored-semen at $37^{\circ} \mathrm{C}$ for $1 \mathrm{~h}$, relaxin increases sperm motility without affecting membrane integrity or cAMP levels (Feugang et al., 2015).

Apart from improving the extenders through additives, a recent approach has consisted of magnetizing the semen extender, as magnetized water has higher electron donor ability which could allow free radicals to be better removed. Lee and Park (2015) evaluated whether a previous, short ( $5 \mathrm{~min}$ ) exposure of the extender to different magnetic fields (2000, 4000 and $6000 \mathrm{G}$ ) improved their preservation characteristics over a 7-day storage period. These authors found that plasma membrane integrity after seven days of storage was better preserved when the extender had been exposed to a magnetic field of $4000 \mathrm{G}$. In addition, in vitro fertilization outcomes using semen preserved for seven days were also higher when the extender had been previously magnetized at $6000 \mathrm{G}$.

\section{Individual response to liquid storage}

There is a high individual variability in terms of sperm processing through different techniques, including liquid storage at $15-17^{\circ} \mathrm{C}$, cryopreservation, and sex-sorting of liquid and frozen-thawed sperm, which indicates that the response to semen-processing techniques heavily relies upon each individual boar/ejaculate (Parrilla et al., 2012). In this context, an interesting issue regards to whether there is any interaction between breeds and extenders. MartínHidalgo et al. (2013) investigated the use of MR-A (Kubus) and X-Cell (IMV Technologies) extenders in Duroc and Iberian breeds over a storage period of 7 days, and found that sperm viability did not differ between extenders or breeds. Instead, sperm motility differed between breeds, and while the extender that yielded the best results for Iberian breed was X-Cell, both extenders gave similar results in Duroc breed. In contrast, the effects of storing boar sperm at $18^{\circ} \mathrm{C}$ on chromatin integrity have been found to be independent from the breed (Duroc, Landrace, Hampshire, and Danish Large White; Boe-Hansen et al., 2005). Therefore, while more research is required to address the potential breed-effect, the current consensus is that individual rather than breed differences exist.

\section{Cryopreservation of boar sperm}

\section{Introduction}

As aforementioned, pig breeding is mainly performed through AI using extended boar semen. Only in $1 \%$ of cases, frozen-thawed semen is utilised and this 
is not only explained by the high costs, necessity of equipment and trained staff, but also because of the reduced fertilizing ability which results from sperm cryodamage (See Yeste, 2015, 2016 for reviews). However, cryopreserved boar sperm may be advised in some cases, as that of germplasm banks, and the advances made in the last years have allowed to reach acceptable reproductive performances.

The discovery of glycerol was an important forward step for the cryopreservation of mammalian sperm. In addition, boar sperm cryopreservation also benefited from the use of controlled-rate freezers, as damages inflicted upon the cell are much greater otherwise. In effect, whereas one may cryopreserve mammalian sperm through the conventional method (i.e. nitrogen vapours and immersion into liquid nitrogen), the use of controlled-rate freezers significantly increases boar sperm survival at post-thawing.

\section{Detrimental effects of cryopreservation}

Although significant advances in the optimization of boar sperm cryopreservation have been made in the last two decades, freeze-thawing protocols negatively impact on sperm function and survival, which also underlies a further reduction in the reproductive performance (Johnson et al., 2000; Yeste, 2015, 2016). Figure 1 and the following subsections are intended to summarise the main cryoinjuries resulting from freeze-thawing procedures.

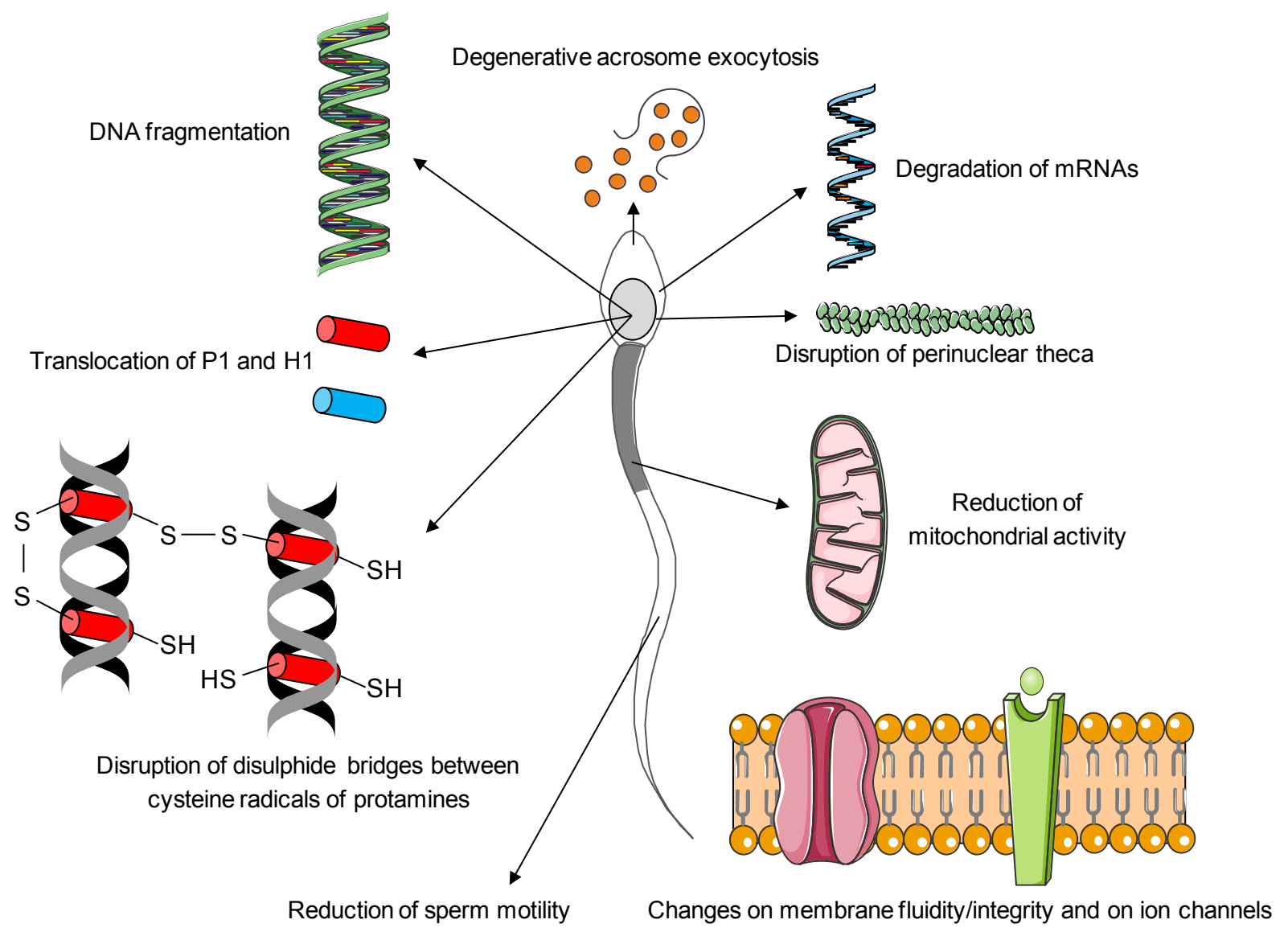

Figure 1. Main cryoinjuries in boar sperm. From Yeste (2016) with permission.

\section{Plasma membrane integrity}

As aforementioned, plasma membrane of boar spermatozoa contains high levels of unsaturated phospholipids and low amounts of cholesterol, which makes these cells very sensitive to cold shock (Casas and Flores, 2013). Therefore, temperatures equal to or lower than $5^{\circ} \mathrm{C}$ lead the plasma membrane to destabilize, and this affects $\mathrm{Ca}^{2+}$ homeostasis, acrosome integrity and membrane lipid packaging (Watson, 2000; Johnson et al., 2000; Cerolini et al., 2001; Bailey et al., 2008). During cold shock, there are lipid-phase separations which cluster integral membrane proteins, release cholesterol molecules and disrupt lipid and protein interactions (Harrison and Miller, 2000; Vadnais and Althouse, 2011). All these changes affect the function of some proteins, such as ions channels, and the selective permeability of plasma membrane, which leads to an increase in the influx of some ions (e.g. $\mathrm{Ca}^{2+}$ ) from the extracellular space (Johnson et al., 2000; Watson, 2000; Bailey et al., 2008).

\section{Sperm motility}

Significant decreases in the percentages of total and progressive motile spermatozoa and in the values of kinetic parameters are very apparent following freezethawing (Flores et al., 2009; Yeste et al., 2013a, b, 2014; Estrada et al., 2014; Fig. 1). However, the reduction of all these sperm motility parameters is 
greatly influenced by ejaculate freezability, as ejaculates with poor freezability present significantly lower motility values than those with good freezability (Yeste et al., 2013a, 2014).

\section{Chromatin integrity}

The integrity of sperm chromatin is also affected by freeze-thawing procedures, and this damage regards to nucleoproteins (mainly protamines), DNA and the interaction between protamines and DNA. On the one hand, cryopreservation of boar spermatozoa has been reported to induce changes in the localization of protamine 1 (P1) and histone 1 (H1; Flores et al., 2008, 2011; Fig. 1). In addition, there is an increase in DNA fragmentation, although this damage may not be apparent upon thawing (Flores et al., 2011) but rather it may be latent and only evident after incubating frozenthawed sperm at $37^{\circ} \mathrm{C}$ for at least $2 \mathrm{~h}$ (Alkmin et al., 2013; Yeste et al., 2013a, b). Cryopreservation of boar sperm also results in an increase in the disrupted disulphide bridges between cysteine radicals of protamines (Flores et al., 2011; Yeste et al., 2013a). This effect has not only been observed in porcine spermatozoa but also in other mammalian species, such as equine (Yeste et al., 2015).

\section{Mitochondrial activity and ROS generation}

While cryopreservation is known to reduce mitochondrial activity in boar sperm (Flores et al., 2010; Fig. 1), the increase of intracellular ROS levels in response to cryopreservation, which has been reported in other mammalian species, is less clear (Guthrie and Welch, 2006; Awda et al., 2009; Kim et al., 2011; Yeste et al., 2013b). In effect, basal levels of peroxides and superoxides in fresh and frozen-thawed boar sperm are low (Guthrie and Welch, 2006, 2012). Flores et al. (2010) found that cryopreservation decreased the capacity of mitochondria to produce ROS. With regard to differences between ejaculates of different freezability, Gómez-Fernández et al. (2013) and Yeste et al. (2013a) found that intracellular levels of ROS and proportions of sperm exhibiting membrane lipid peroxidation did not differ between ejaculates with different resilience to withstand freeze-thawing procedures.

\section{Other impact: proteins and $m R N A$}

As aforementioned, the function of some relevant proteins, such as ion channels, may be compromised as a result of cryopreservation (Kim et al., 2008). It is also worth noting that freeze-thawing induces changes in the localization of proteins, such as actin and mitofusin 2 (Flores et al., 2010) and glucose transporter GLUT3 (Sancho et al., 2007). Moreover, cryopreservation may also lead to premature phosphorylation of specific sperm proteins, as that of p32 (which probably corresponds to acrosin binding protein) following cooling and freeze-thawing (Kumaresan et al., 2011).
Cryopreservation has also been reported to reduce the levels of certain mRNAs, probably because of their degradation or as a result of the loss of the selective permeability of plasma membrane (Zeng et al., 2014; Fig. 1).

\section{Ejaculate resilience to withstand cryopreservation}

As aforementioned, there is a high variability in the response of ejaculates to sperm processing techniques, including the preservation of liquid and cryopreserved boar sperm (Parrilla et al., 2012). In the latter case, this high variability has led to classify boar ejaculates as good or poor freezability ejaculates (Watson, 1995; Casas et al., 2009), where freezability is defined as the ability to sustain freeze-thawing procedures (Yeste, 2016). The high individual variability is not only restricted to boars, but has also been observed between ejaculates coming from the same boar and even between fractions of the same ejaculate (Holt, 2000; Holt et al., 2005; Peña et al., 2006; Waterhouse et al., 2006; Yeste et al., 2013a).

Good (GFE) and poor freezability ejaculates (PFE) exhibit different motility and sperm membrane integrity following freeze-thawing (Casas et al., 2009; Yeste et al., 2013a). Apart from more research still being required to address the mechanisms that underlie the different response of GFE and PFE cryopreservation, a main inconvenient is that conventional spermiogram parameters evaluated in fresh semen do not give an accurate prediction of ejaculate freezability (reviewed in Yeste, 2015, 2016). In this context, it is worth mentioning that the levels of certain proteins in fresh/extended sperm appear to confer higher resilience to withstand freezethawing procedures. These proteins, which have been identified in sperm and seminal plasma, are known as freezability markers and their relative levels evaluated in fresh sperm should allow the prediction of sperm cryotolerance prior to conducting freeze-thawing procedures.

In the case of sperm, freezability markers are membrane channels and other proteins that appear to be involved in the response to osmotic and thermal stresses. Thus far, the following sperm freezability markers have been identified: heat shock protein 90 (HSP90AA1), acrosin binding protein (ACRBP), triosephosphate isomerase (TPI) and voltage-dependent anion channel 2 (VDAC2; Casas et al., 2010a; Vilagran et al., 2013, 2014). Acrosin activity in fresh sperm is also related to ejaculate freezability, the ejaculates presenting higher cryotolerance being those with higher acrosin activity (Estrada et al., 2015; Pinart et al., 2015b).

With regard to seminal plasma, relative amounts of fibronectin 1 (FN1) in fresh seminal plasma have been reported to predict ejaculate freezability (Vilagran et al., 2015). In addition, the activity of $\mathrm{N}$ acetyl- $\beta$-hexosaminidase in fresh seminal plasma has been found to be negatively correlated with sperm motility, survival and lipid peroxidation, which indicates that high levels of $\beta$-HEX activity are linked to low resilience to withstand freeze-thawing procedures 
(Wysocki et al., 2015).

\section{Cryopreservation extenders}

\section{LEY and LEYGO}

In pigs, sperm cryopreservation takes place in two steps. A first step consists of gradually decreasing the temperature from $15-17^{\circ} \mathrm{C}$ to $5^{\circ} \mathrm{C}$ (this process lasts between 30 and $240 \mathrm{~min}$, depending on the protocol). In the second step, the temperature is decreased from 5 to $196^{\circ} \mathrm{C}$ (Eriksson and Rodríguez-Martínez, 2000; Casas et al., 2009). The extenders used in both steps (LEY and LEYGO) contain buffer systems (like Tris), detergent agents and non-permeating cryoprotectant agents (CPAs), such as egg yolk and sugars (Hu et al., 2012; Benson et al., 2012). Non-permeating CPAs do not pass through plasma membrane and develop its role extracellularly. The combination of egg yolk with the surfactant Orvus ES Paste (Equex) facilitates the interaction of egg yolk proteins with the sperm plasma membrane (Holt, 2000; Rodríguez-Martinez and Wallgren, 2011). In addition, LEYGO, which is the freezing extender used for the second step contains glycerol, a permeating $\mathrm{CPA}(\mathrm{Gao}$ and Critser, 2000; Gadea, 2003). Therefore, the inclusion of CPAs is critical as slow freezing may lead to form ice crystals within the cell and the presence of CPAs may help prevent the formation of such crystals. That being said, CPAs are usually harmful for the cell upon thawing and it is thus critical to use the proper concentration and proceed to a quick removal.

Previous works have evaluated the impact of replacing one of the non-permeable CPAs (egg yolk) by low-density lipoproteins (LDL), which are part of the egg yolk mixture and are thought to exert the protective effect. These reports concur that replacing the egg yolk by LDL increases boar sperm quality and chromatin integrity as the assessment of sperm at post-thawing indicates (Fraser and Strzezek, 2007; Fraser et al., 2007; Hu et al., 2008).

With regard to permeating CPAs, glycerol is the most commonly used CPA, despite other agents such as dimethylsulfoxide (DMSO) being used for cryopreserving sperm in other mammalian species. Permeating CPAs decrease the concentration of cytoplasm electrolytes and reduce the extent of osmotic shrinkage at low temperatures (Mazur, 1984; Gao and Critser, 2000). In the case of boar sperm, no permeating CPA has yielded better results than glycerol (Buranaamnuay et al., 2011; Malo et al., 2012) and its optimal concentrations have been reported to range between 2 and 3\% (Buhr et al., 2001; Okazaki et al., 2009; Zeng et al., 2014).

\section{Improvement of cryopreservation extenders}

Different attempts have aimed at improving the sperm function and survival at post-thawing by supplementing freezing and thawing extenders with different additives. The present section discusses the additives that have given better results, such as seminal plasma, cholesterol-loaded cyclodextrins and antioxidants.

The addition of seminal plasma (5\%) obtained from GFE to freezing extenders increases the survival, motility, and in vitro fertilization outcomes of frozenthawed sperm of poor freezability ejaculates (Hernández et al., 2007). The results of adding thawing medium with seminal plasma are less clear as whereas some authors indicate that it is beneficial for sperm motility and membrane integrity (Gómez-Fernández et al., 2012; Okazaki and Shimada, 2012), others report that it leads to a decrease in the proportions of sperm exhibiting an intact plasma membrane (Fernández-Gago et al., 2013). Since conditions between studies differ, more research is required to address this inconsistency.

The addition of cholesterol-loaded cyclodextrins (CLC) to freezing extenders has been reported to increase the levels of cholesterol in the plasma membrane, which results in an augment in the stability of that membrane and thus in the post-thaw sperm survival and fertilizing ability (Tomás et al., 2011, 2013; Blanch et al., 2012).

Supplementing freezing and thawing extenders with different antioxidants has also been tested as a way to improve the sperm quality at post-thawing. There is quite a long list of antioxidants tested that have been reported to provide good results, including L-cysteine, $\alpha$-tocopherol, lutein, butylated hydroxytoluene, Trolox, reduced glutathione and ascorbic acid (Roca et al., 2004; Chanapiwat et al., 2009; Jeong et al., 2009; Kaeoket et al., 2010; Satorre et al., 2012; Giaretta et al., 2015; Varo-Ghiuru et al., 2015). Among them, reduced glutathione is one of those that have been more extensively studied and has been found to increase sperm quality at post-thawing and augment the fertilizing ability both in vivo and in vitro (Gadea et al., 2005; Yeste et al., 2013a, 2014; Estrada et al., 2014, 2015; Giaretta et al., 2015).

\section{Fertility of frozen-thawed boar sperm}

It is generally understood that the reproductive performance of cryopreserved boar sperm is lower than that of fresh/extended semen (Knox, 2015). In spite of this, the research conducted in the last decades has allowed to increase the fertilizing ability of frozenthawed sperm. In effect, recent reports indicate that litter sizes equal to or higher than ten piglets born per litter may be obtained (Didion et al., 2013; Knox, 2015). In addition to this, both farrowing rates and litter sizes may be increased if additives such as reduced glutathione are used (Estrada et al., 2014; Knox, 2015).

A very important point to be kept in mind is the AI technique used for insemination, with post-cervical and deep intrauterine insemination being more suitable than conventional AI (Martínez et al., 2001; Casas et al., 2010b). Other aspects that must be taken into account are the interval of insemination-to-ovulation and the fact that AI with frozen-thawed sperm yields better results when double insemination is performed (Spencer et al., 2010). If all these points are not considered, the risk of a dramatic drop in reproductive 
performance is very high.

\section{Conclusions}

Artificial insemination is widely used for pig breeding. Most of AIs are conducted with extended semen, as the capacity of extenders to preserve sperm quality and fertilizing ability allows obtaining high farrowing rates and litter sizes. In contrast, boar sperm cryopreservation is not routinely used as, despite being the most effective method for long-term preservation of mammalian sperm, it is costly and may reduce sperm quality and fertilizing ability. In spite of this, boar sperm cryopreservation may be advised in some cases, as that of germplasm banks, and the advances made in the last years have led to reach acceptable reproductive performances.

\section{Acknowledgments}

The author acknowledges the support from the Ministry of Economy and Competitiveness, Spain (Grant Id: RYC-2014-15581).

\section{References}

Alkmin DV, Martinez-Alborcia MJ, Parrilla I, Vazquez JM, Martinez EA, Roca J. 2013. The nuclear DNA longevity in cryopreserved boar spermatozoa assessed using the Sperm-Sus-Halomax. Theriogenology, 79:1294-1300.

Althouse GC, Wilson ME, Kuster C, Parsley M. 1998. Characterization of lower temperature storage limitations of fresh-extended porcine semen. Theriogenology, 50:535-543.

Althouse GC, Kuster CE, Clark SG, Weisiger RM. 2000. Field investigations of bacterial contaminants and their effects on extended porcine semen. Theriogenology, 53:1167-1176.

Awda BJ, Mackenzie-Bell M, Buhr MM. 2009. Reactive oxygen species and boar sperm function. Biol Reprod, 81:553-561.

Bailey JL, Lessard C, Jacques $\mathbf{J}$, Brèque C, Dobrinski I, Zeng W, Galantino-Homer HL. 2008 Cryopreservation of boar semen and its future importance to the industry. Theriogenology, 70:12511259.

Benson JD, Woods EJ, Walters EM, Critser JK. 2012. The cryobiology of spermatozoa. Theriogenology, 78:1682-1699.

Blanch E, Tomás C, Graham JK, Mocé E. 2012. Response of boar sperm to the treatment with cholesterol-loaded cyclodextrins added prior to cryopreservation. Reprod Domest Anim, 47:959-964.

Boe-Hansen GB, Ersbøll AK, Greve T, Christensen P. 2005. Increasing storage time of extended boar semen reduces sperm DNA integrity. Theriogenology, 63:2006-2019.

Bryła M, Trzcińska M. 2015. Quality and fertilizing capacity of boar spermatozoa during liquid storage in extender supplemented with different antibiotics. Anim Reprod Sci, 163:157-163.
Buhr MM, Canvin AT, Bailey JL. 1989. Effects of semen preservation on boar spermatozoa head membranes. Gamete Res, 23:441-449.

Buhr MM, Fiser P, Bailey JL, Curtis EF. 2001. Cryopreservation in different concentrations of glycerol alters boar sperm and their membranes. J Androl, 22:961-969.

Buranaamnuay K, Grossfeld R, Struckmann C, Rath D. 2011. Influence of cryoprotectants glycerol and amides, combined with antioxidants on quality of frozen-thawed boar sperm. Anim Reprod Sci, 127:56-61. Bussalleu E, Yeste M, Sepúlveda L, Torner E, Pinart E, Bonet S. 2011. Effects of different concentrations of enterotoxigenic and verotoxigenic E. coli on boar sperm quality. Anim Reprod Sci, 127:176-182.

Casas I, Sancho S, Briz M, Pinart E, Bussalleu E, Yeste M, Bonet S. 2009. Freezability prediction of boar ejaculates assessed by functional sperm parameters and sperm proteins. Theriogenology, 72:930-948.

Casas I, Sancho S, Ballester J, Briz M, Pinart E, Bussalleu E, Yeste M, Fàbrega A, Rodríguez-Gil JE, Bonet S. 2010a. The HSP90AA1 sperm content and the prediction of the boar ejaculate freezability. Theriogenology, 74:940-950.

Casas I, Sancho S, Briz M, Pinart E, Bussalleu E, Yeste M, Bonet S. 2010b. Fertility after post-cervical artificial insemination with cryopreserved sperm from boar ejaculates of good and poor freezability. Anim Reprod Sci, 118:69-76.

Casas I, Flores E. 2013. Gene banking: the freezing strategy. In: Bonet S, Casas I, Holt WV, Yeste M (Ed.). Boar Reproduction. Berlin: Springer. pp. 551-588.

Cerolini S, Maldjian A, Pizzi F, Gliozzi TM. 2001. Changes in sperm quality and lipid composition during cryopreservation of boar semen. Reproduction, 121:395-401.

Chanapiwat P, Kaeoket K, Tummaruk P. 2009. Effects of DHA-enriched hen egg yolk and L-cysteine supplementation on quality of cryopreserved boar semen. Asian J Androl, 11:600-608.

De Ambrogi M, Ballester J, Saravia F, Caballero I, Johannisson A, Wallgren $M$, Andersson $M$, Rodriguez-Martinez H. 2006. Effect of storage in short--and long-term commercial semen extenders on the motility, plasma membrane and chromatin integrity of boar spermatozoa. Int J Androl, 29:543-552.

Didion BA, Braun GD, Duggan MV. 2013. Field fertility of frozen boar semen: a retrospective report comprising over 2600 AI services spanning a four year period. Anim Reprod Sci, 137:189-196.

Dubé C, Beaulieu M, Reyes-Moreno C, Guillemette C, Bailey JL. 2004. Boar sperm storage capacity of BTS and Androhep Plus: viability, motility, capacitation, and tyrosine phosphorylation. Theriogenology, 62:874-886.

Eriksson BM, Rodriguez-Martinez H. 2000. Effect of freezing and thawing rates on the post-thaw viability of boar spermatozoa frozen in FlatPacks and Maxi-straws. Anim Reprod Sci, 63:205-220.

Estienne MJ, Harper AF, Day JL. 2007. Characteristics of sperm motility in boar semen diluted in different extenders and stored for seven days at 18 
degrees C. Reprod Biol, 7:221-231.

Estrada E, Rodríguez-Gil JE, Rocha LG, Balasch S, Bonet S, Yeste M. 2014. Supplementing cryopreservation media with reduced glutathione increases fertility and prolificacy of sows inseminated with frozen-thawed boar semen. Andrology, 2:88-99.

Estrada E, Rodríguez-Gil JE, Rivera Del Álamo MM, Peña A, Yeste M. 2015. Effects of reduced glutathione on acrosin activity in frozen-thawed boar spermatozoa. Reprod Fertil Dev. doi: 10.1071/RD15118

Fantinati P, Zannoni A, Bernardini C, Forni M, Tattini A, Seren E, Bacci ML. 2009. Evaluation of swine fertilisation medium (SFM) efficiency in preserving spermatozoa quality during long-term storage in comparison to four commercial swine extenders. Animal, 3:269-274.

Fernández-Gago R, Domínguez JC, Martínez-Pastor F. 2013. Seminal plasma applied post-thawing affects boar sperm physiology: a flow cytometry study. Theriogenology, 80:400-410.

Feugang JM, Rodríguez-Muñoz JC, Dillard DS, Crenshaw MA, Willard ST, Ryan PL. 2015 Beneficial effects of relaxin on motility characteristics of stored boar spermatozoa. Reprod Biol Endocrinol, 13:24. doi: 10.1186/s12958-015-0021-4.

Flores E, Cifuentes D, Fernández-Novell JM, Medrano A, Bonet S, Briz MD, Pinart E, Peña A, Rigau T, Rodríguez-Gil JE. 2008. Freeze-thawing induces alterations in the protamine-1/DNA overall structure in boar sperm. Theriogenology, 69:1083-1094. Flores E, Fernández-Novell JM, Peña A, RodríguezGil JE. 2009. The degree of resistance to freezingthawing is related to specific changes in the structures of motile sperm subpopulations and mitochondrial activity in boar spermatozoa. Theriogenology, 72:784-797.

Flores E, Fernández-Novell JM, Peña A, Rigau T, Rodríguez-Gil JE. 2010. Cryopreservation-induced alterations in boar spermatozoa mitochondrial function are related to changes in the expression and location of midpiece mitofusin-2 and actin network. Theriogenology, 74:354-363.

Flores E, Ramió-Lluch L, Bucci D, Fernández-Novell JM, Peña A, Rodríguez-Gil JE. 2011. Freezingthawing induces alterations in histone H1-DNA binding and the breaking of protein-DNA disulfide bonds in boar sperm. Theriogenology, 76:1450-1464.

Fraser L, Gorszczaruk K, Strzezek J. 2001. Relationship between motility and membrane integrity of boar spermatozoa in media varying in osmolality. Reprod Domest Anim, 36:325-329.

Fraser L, Strzeżek J. 2007. Effect of different procedures of ejaculate collection, extenders and packages on DNA integrity of boar spermatozoa following freezing-thawing. Anim Reprod Sci, 99:317-329.

Fraser L, Strzezek R, Strzeżek J. 2007. Fertilizing capacity of boar semen frozen in an extender supplemented with ostrich egg yolk lipoprotein fractions - a pilot study. Pol J Vet Sci, 10:131-135.

Gadea J. 2003. Semen extenders used in artificial insemination of swine. A review. Span J Agric Res, $1: 17-27$
Gadea J, García-Vázquez FA, Matás C, Gardón JC, Cánovas S, Gumbao D. 2005. Cooling and freezing of boar spermatozoa: supplementation of the freezing media with reduced glutathione preserves sperm function. $J$ Androl, 26:396-404.

Gao D, Critser JK. 2000. Mechanisms of cryoinjury in living cells. ILAR $J, 41: 187-196$.

Giaretta E, Estrada E, Bucci D, Spinaci M, Rodríguez-Gil JE, Yeste M. 2015. Combining reduced glutathione and ascorbic acid has supplementary beneficial effects on boar sperm cryotolerance. Theriogenology, 83:399-407.

Gogol P, Szcześniak-Fabiańczyk B，WierzchośHilczer A. 2009. The photon emission, ATP level and motility of boar spermatozoa during liquid storage. Reprod Biol, 9:39-49.

Gómez-Fernández J, Gómez-Izquierdo E, Tomás C, Mocé E, de Mercado E. 2012. Effect of different monosaccharides and disaccharides on boar sperm quality after cryopreservation. Anim Reprod Sci, 133:109-116.

Gómez-Fernández J, Gómez-Izquierdo E, Tomás C, Mocé E, de Mercado E. 2013. Is sperm freezability related to the post-thaw lipid peroxidation and the formation of reactive oxygen species in boars? Reprod Domest Anim, 48:177-182.

Guthrie HD, Welch GR. 2006. Determination of intracellular reactive oxygen species and high mitochondrial membrane potential in Percoll-treated viable boar sperm using fluorescence-activated flow cytometry. J Anim Sci, 84:2089-2100

Guthrie HD, Welch GR, Long JA. 2008. Mitochondrial function and reactive oxygen species action in relation to boar motility. Theriogenology, 70:1209-1215

Harrison RA, Dott HM, Foster GC. 1978. Effect of ionic strength, serum albumin and other macromolecules on the maintenance of motility and the surface of mammalian spermatozoa in a simple medium. $J$ Reprod Fertil, 52:65-73.

Harrison RA. 1997. Sperm plasma membrane characteristics and boar semen fertility. $J$ Reprod Fertil Suppl, 52:195-211.

Harrison RA, Miller NG. 2000. cAMP-dependent protein kinase control of plasma membrane lipid architecture in boar sperm. Mol Reprod Dev, 55:220228 .

Haugan T, Gaustad AH, Reksen O, Gröhn YT, Hofmo PO. 2007. Fertility results of artificial inseminations performed with liquid boar semen stored in X-cell vs BTS extender. Reprod Domest Anim, 42:9499.

Henning H, Petrunkina AM, Harrison RA, Waberski D. 2012. Bivalent response to long-term storage in liquid-preserved boar semen: a flow cytometric analysis. Cytometry A, 81:576-587.

Henning H, Petrunkina AM, Harrison RA, Waberski D. 2014. Cluster analysis reveals a binary effect of storage on boar sperm motility function. Reprod Fertil Dev, 26:623-632.

Hernández M, Roca J, Calvete JJ, Sanz L, MuiñoBlanco T, Cebrián-Pérez JA, Vázquez JM, Martínez 
EA. 2007. Cryosurvival and in vitro fertilizing capacity postthaw is improved when boar spermatozoa are frozen in the presence of seminal plasma from good freezer boars. J Androl, 28:689-697.

Holt WV. 2000. Basic aspects of frozen storage of semen. Anim Reprod Sci, 62:3-22.

Holt WV, Medrano A, Thurston LM, Watson PF. 2005. The significance of cooling rates and animal variability for boar sperm cryopreservation: insights from the cryomicroscope. Theriogenology, 63:370-382.

Hu JH, Li QW, Jiang ZL, Li WY. 2008. Effects of different extenders on DNA integrity of boar spermatozoa following freezing-thawing. Cryobiology, 57:257-262

Hu JH, Li QW, Jiang ZL, Yang H, Zhang SS, Zhao HW. 2009. The cryoprotective effect of trehalose supplementation on boar spermatozoa quality. Reprod Domest Anim, 44:571-575.

Huo LJ, Yue KZ, Yang ZM. 2002a. Characterization of viability, mitochondrial activity, acrosomal integrity and capacitation status in boar sperm during in vitro storage at different ambient temperatures. Reprod Fertil Dev, 14:509-514.

Huo LJ, Ma XH, Yang ZM. 2002b. Assessment of sperm viability, mitochondrial activity, capacitation and acrosome intactness in extended boar semen during long-term storage. Theriogenology, 58:1349-1360.

Jeong YJ, Kim MK, Song HJ, Kang EJ, Ock SA, Kumar BM, Balasubramanian S, Rho GJ. 2009 Effect of alpha-tocopherol supplementation during boar semen cryopreservation on sperm characteristics and expression of apoptosis related genes. Cryobiology, 58:181-189.

Johnson LA, Aalbers JG, Willems CM, Rademaker JH, Rexroad CE Jr. 1982. Use of boar spermatozoa for artificial insemination. III. Fecundity of boar spermatozoa stored in Beltsville liquid and Kiev extenders for three days at 18C. J Anim Sci, 54:132-136. Johnson LA, Weitze KF, Fiser P, Maxwell WM. 2000. Storage of boar semen. Anim Reprod Sci, 62:143172.

Kaeoket K, Chanapiwat P, Tummaruk P, Techakumphu M. 2010. Supplemental effect of varying L-cysteine concentrations on the quality of cryopreserved boar semen. Asian J Androl, 12:760-765. Kim JC, Li Y, Lee S, Yi YJ, Park CS, Woo SH. 2008. Effects of cryopreservation on $\mathrm{Ca} 2+$ signals induced by membrane depolarization, caffeine, thapsigargin and progesterone in boar spermatozoa. Mol Cells, 26:558565.

Kim S, Lee YJ, Kim YJ. 2011. Changes in sperm membrane and ROS following cryopreservation of liquid boar semen stored at $15^{\circ} \mathrm{C}$. Anim Reprod Sci, 124:118-124.

Knox RV. 2015. The fertility of frozen boar sperm when used for artificial insemination. Reprod Domest Anim, 50(suppl 2):90-97.

Kommisrud E, Paulenz H, Sehested E, Grevle IS 2002. Influence of boar and semen parameters on motility and acrosome integrity in liquid boar semen stored for five days. Acta Vet Scand, 43:49-55.

Kumaresan A, Siqueira AP, Hossain MS, Bergqvist
AS. 2011. Cryopreservation-induced alterations in protein tyrosine phosphorylation of spermatozoa from different portions of the boar ejaculate. Cryobiology, 63:137-144.

Kuster CE, Althouse GC. 1999. The fecundity of porcine semen stored for 2 to 6 days in Androhep and X-CELL extenders. Theriogenology, 52:365-376.

Lee SH, Park CK. 2015. Effect of magnetized extender on sperm membrane integrity and development of oocytes in vitro fertilized with liquid storage boar semen. Anim Reprod Sci, 154:86-94.

López Rodríguez A, Rijsselaere T, Vyt P, Van Soom A, Maes D. 2012. Effect of dilution temperature on boar semen quality. Reprod Domest Anim, 47:e63-e66.

Malo C, Gil L, Cano R, Martínez F, García A, Jerez RA. 2012. Dimethylformamide is not better than glycerol for cryopreservation of boar semen. Andrologia, 44(suppl 1):605-610.

Martín-Hidalgo D, Barón FJ, Bragado MJ, Carmona P, Robina A, García-Marín LJ, Gil MC. 2011. The effect of melatonin on the quality of extended boar semen after long-term storage at $17^{\circ} \mathrm{C}$. Theriogenology, 75:1550-1560.

Martín-Hidalgo D, Barón FJ, Robina A, Bragado MJ, Llera AH, García-Marín LJ, Gil MC. 2013. Inter- and intra-breed comparative study of sperm motility and viability in Iberian and Duroc boar semen during long-term storage in MR-A and XCell extenders. Anim Reprod Sci, 139:109-114.

Martinez EA, Vazquez JM, Roca J, Lucas X, Gil MA, Vazquez JL. 2001. Deep intrauterine insemination and embryo transfer in pigs. Reproduction Suppl, 58:301-311.

Mazur P. 1984. Freezing of living cells: Mechanisms and implications. Am J Physiol, 247 (Cell Physiol 16):C125-C142.

Medrano A, Peña A, Rigau T, Rodríguez-Gil JE. 2005. Variations in the proportion of glycolytic/nonglycolytic energy substrates modulate sperm membrane integrity and function in diluted boar samples stored at 15-17 degrees C. Reprod Domest Anim, 40:448-453.

Murase T, Imaeda N, Yamada H, Takasu M, Taguchi K, Katoh T. 2010. Dilution of boar ejaculates with BTS containing HEPES in place of bicarbonate immediately after ejaculation can reduce the increased inducibility of the acrosome reaction by treatment with calcium and calcium ionophore A23187, which is potentially associated with boar subfertility. $J$ Reprod Dev, 56:309-314.

Nerin C, Ubeda JL, Alfaro P, Dahmani Y, Aznar M, Canellas E, Ausejo R. 2014. Compounds from multilayer plastic bags cause reproductive failures in artificial insemination. Sci Rep, 4:4913. doi: 10.1038/srep04913.

Newth MS, Levis DG. 1999. Changes in pH of Boar Semen Extenders. Nebraska Swine Reports, paper 134. http://digitalcommons.unl.edu/coopext swine/134.

Okazaki T, Abe S, Shimada M. 2009. Improved conception rates in sows inseminated with cryopreserved boar spermatozoa prepared with a more optimal combination of osmolality and glycerol in the freezing extender. Anim Sci J, 80:121-129. 
Okazaki T, Mihara T, Fujita Y, Yoshida S, Teshima H, Shimada M. 2010. Polymyxin B neutralizes bacteria-released endotoxin and improves the quality of boar sperm during liquid storage and cryopreservation. Theriogenology, 74:1691-1700.

Okazaki T, Shimada M. 2012. New strategies of boar sperm cryopreservation: development of novel freezing and thawing methods with a focus on the roles of seminal plasma. Anim Sci J, 83:623-629.

Parrilla I, del Olmo D, Sijses L, Martinez-Alborcia MJ, Cuello C, Vazquez JM, Martinez EA, Roca J 2012. Differences in the ability of spermatozoa from individual boar ejaculates to withstand different semenprocessing techniques. Anim Reprod Sci, 132:66-73.

Peña FJ, Saravia F, Núñez-Martínez I, Johannisson A, Wallgren M, Rodríguez Martínez H. 2006. Do different portions of the boar ejaculate vary in their ability to sustain cryopreservation? Anim Reprod Sci, 93:101-113.

Pérez-Llano B, Sala R, Reguera G, García-Casado P. 2009. Changes in subpopulations of boar sperm defined according to viability and plasma and acrosome membrane status observed during storage at 15 degrees C. Theriogenology, 71:311-317.

Pinart E, Yeste M, Puigmulé M, Barrera X, Bonet S. 2013. Acrosin activity is a suitable indicator of boar semen preservation at $17{ }^{\circ} \mathrm{C}$ when increasing environmental temperature and radiation. Theriogenology, 80:234-247.

Pinart E, Yeste M, Prieto-Martínez N, Reixach J, Bonet S. 2015a. Sperm quality and fertility of boar seminal doses after 2 days of storage: does the type of extender really matter? Theriogenology, 83:1428-1437.

Pinart E, Yeste M, Bonet S. 2015b. Acrosin is a good predictor of boar sperm freezability. Theriogenology, 83:1525-1533.

Prieto-Martínez N, Bussalleu E, Garcia-Bonavila E, Bonet S, Yeste M. 2014. Effects of Enterobacter cloacae on boar sperm quality during liquid storage at $17^{\circ} \mathrm{C}$. Anim Reprod Sci, 148:72-82.

Purdy PH, Tharp N, Stewart T, Spiller SF, Blackburn HD. 2010. Implications of the $\mathrm{pH}$ and temperature of diluted, cooled boar semen on fresh and frozen-thawed sperm motility characteristics. Theriogenology, 74:1304-1310.

Pursel VG, Johnson LA, Schulman LL. 1973. Fertilizing capacity of boar semen stored at $15^{\circ} \mathrm{C} . J$ Anim Sci, 37: 532-535.

Roca J, Gil MA, Hernandez M, Parrilla I, Vazquez JM, Martinez EA. 2004. Survival and fertility of boar spermatozoa after freeze-thawing in extender supplemented with butylated hydroxytoluene. J Androl, 25:397-405.

Rodriguez-Martinez H, Wallgren M. 2011. Advances in boar semen cryopreservation. Vet Med Int. doi: $10.4061 / 2011 / 396181$

Rodríguez-Gil JE. 2013. Biological aspects of the mature spermatozoon. In: Bonet S, Casas I, Holt WV, Yeste M (Ed.). Boar Reproduction. Berlin: Springer. pp. 49-64.

Rodríguez-Gil JE, Estrada E. 2013. Artificial insemination in boar reproduction. In: Bonet S, Casas I,
Holt WV, Yeste M (Ed.). Boar Reproduction. Berlin: Springer. pp. 589-608.

Sancho S, Casas I, Ekwall H, Saravia F, RodriguezMartinez H, Rodriguez-Gil JE, Flores E, Pinart E, Briz M, Garcia-Gil N, Bassols J, Pruneda A, Bussalleu E, Yeste M, Bonet S. 2007. Effects of cryopreservation on semen quality and the expression of sperm membrane hexose transporters in the spermatozoa of Iberian pigs. Reproduction, 134:111121.

Satorre MM, Breininger E, Beconi MT. 2012. Cryopreservation with $\alpha$-tocopherol and Sephadex filtration improved the quality of boar sperm. Theriogenology, 78:1548-1556.

Schilling E, Vengust M. 1986. Osmotic pressure of boar semen. Reprod Domest Anim, 21:33-34.

Schmid S, Henning H, Petrunkina AM, Weitze KF, Waberski D. 2013a. Response to capacitating stimuli indicates extender-related differences in boar sperm function. J Anim Sci, 91:5018-5025.

Schmid S, Henning H, Oldenhof H, Wolkers WF, Petrunkina AM, Waberski D. 2013b. The specific response to capacitating stimuli is a sensitive indicator of chilling injury in hypothermically stored boar spermatozoa. Andrology, 1:376-386.

Schulze M, Rüdiger K, Waberski D. 2015. Rotation of boar semen doses during storage affects sperm quality. Reprod Domest Anim, 50:684-687.

Sepúlveda L, Bussalleu E, Yeste M, Torner E, Bonet S. 2013. How do different concentrations of Clostridium perfringens affect the quality of extended boar spermatozoa? Anim Reprod Sci, 140:83-91.

Sepúlveda L, Bussalleu E, Yeste M, Bonet S. 2014. Effects of different concentrations of Pseudomonas aeruginosa on boar sperm quality. Anim Reprod Sci, 150:96-106.

Sepúlveda L, Bussalleu E, Yeste M, Bonet S. 2016. Effect of Pseudomonas aeruginosa on sperm capacitation and protein phosphorylation of boar spermatozoa. Theriogenology, 85:1421-1431.

Sone M, Ohmura K, Bamba K. 1982. Effects of various antibiotics on the control of bacteria in boar semen. Vet Rec, 111:11-14.

Spencer KW, Purdy PH, Blackburn HD, Spiller SF, Stewart TS, Knox RV. 2010. Effect of number of motile, frozen-thawed boar sperm and number of fixedtime inseminations on fertility in estrous-synchronized gilts. Anim Reprod Sci, 121:259-266.

Suzuki C, Yoshioka K, Itoh S, Kawarasaki T, Kikuchi K. 2005. In vitro fertilization and subsequent development of porcine oocytes using cryopreserved and liquid-stored spermatozoa from various boars. Theriogenology, 64:1287-1296.

Tomás C, Blanch E, Hernández M, Gil MA, Roca J, Vázquez JM, Martínez EA, Mocé E. 2011. Treating boar sperm with cholesterol-loaded cyclodextrins widens the sperm osmotic tolerance limits and enhances the in vitro sperm fertilising ability. Anim Reprod Sci, 129:209-220.

Tomás C, Blanch E, Fazeli A, Mocé E. 2013. Effect of a pre-freezing treatment with cholesterol-loaded cyclodextrins on boar sperm longevity, capacitation 
dynamics, ability to adhere to porcine oviductal epithelial cells in vitro and DNA fragmentation dynamics. Reprod Fertil Dev, 25:935-946.

Toniolli R, Bussière J, Courot M, Magistrini M, Combarnous Y. 1996. Effect of indole-3-acetic acid (plant auxin) on the preservation at 15 degrees $\mathrm{C}$ of boar semen for artificial insemination. Reprod Nutr Dev, 36:503-511.

Vadnais ML, Althouse GC. 2011. Characterization of capacitation, cryoinjury, and the role of seminal plasma in porcine sperm. Theriogenology, 76:1508-1516.

Varo-Ghiuru F, Miclea I, Hettig A, Ladosi I, Miclea V, Egerszegi I, Zahan M. 2015. Lutein, Trolox, ascorbic acid and combination of Trolox with ascorbic acid can improve boar semen quality during cryopreservation. Cryo Letters, 36:1-7.

Vilagran I, Castillo J, Bonet S, Sancho S, Yeste M, Estanyol JM, Oliva R. 2013. Acrosin-binding protein (ACRBP) and triosephosphate isomerase (TPI) are good markers to predict boar sperm freezing capacity. Theriogenology, 80:443-450.

Vilagran I, Yeste M, Sancho S, Casas I, Rivera del Álamo MM, Bonet S. 2014. Relationship of sperm small heat-shock protein 10 and voltage-dependent anion channel 2 with semen freezability in boars. Theriogenology, 82:418-426.

Vilagran I, Yeste M, Sancho S, Castillo J, Oliva R, Bonet S. 2015. Comparative analysis of boar seminal plasma proteome from different freezability ejaculates and identification of Fibronectin 1 as sperm freezability marker. Andrology, 3:345-356.

Vyt P, Maes D, Dejonckheere E, Castryck F, Van Soom A. 2004. Comparative study on five different commercial extenders for boar semen. Reprod Domest Anim, 39:8-12.

Vyt P, Maes D, Sys SU, Rijsselaere T, Van Soom A. 2007. Air contact influences the $\mathrm{pH}$ of extended porcine semen. Reprod Domest Anim, 42:218-220.

Waberski D, Meding S, Dirksen G, Weitze KF, Leiding C, Hahn R. 1994. Fertility of long-term-stored boar semen: Influence of extender (Androhep and $\mathrm{Kiev}$ ), storage time and plasma droplets in the semen. Anim Reprod Sci, 36:145-151.

Waterhouse KE, De Angelis PM, Haugan T, Paulenz H, Hofmo PO, Farstad W. 2004. Effects of in vitro storage time and semen-extender on membrane quality of boar sperm assessed by flow cytometry. Theriogenology, 62:1638-1651.

Waterhouse KE, Hofmo PO, Tverdal A, Miller Jr RR. 2006. Within and between breed differences in freezing tolerance and plasma membrane fatty acid composition of boar sperm. Reproduction, 131:887-894. Watson PF. 1995. Recent developments and concepts in the cryopreservation of spermatozoa and the assessment of their post-thawing function. Reprod Fertil Dev, 7:871-891.

Watson PF. 2000. The causes of reduced fertility with cryopreserved semen. Anim Reprod Sci, 60/61:481-492.

White IG. 1993. Lipids and calcium uptake of sperm in relation to cold shock and preservation: a review. Reprod Fertil Dev, 5:639-658.

Wysocki P, Orzołek A, Strzeżek J, KoziorowskaGilun M, Zasiadczyk L, Kordan W. 2015. The activity of $\mathrm{N}$-acetyl- $\beta$-hexosaminidase in boar seminal plasma is linked with semen quality and its suitability for cryopreservation. Theriogenology, 83:1194-1202.

Yeste M, Briz M, Pinart E, Sancho S, Garcia-Gil N, Badia E, Bassols J, Pruneda A, Bussalleu E, Casas I, Bonet S. 2008. Hyaluronic acid delays boar sperm capacitation after 3 days of storage at 15 degrees $\mathrm{C}$. Anim Reprod Sci, 109:236-250.

Yeste M. 2013. Boar spermatozoa within the oviductal environment (II): sperm capacitation. In: Bonet S, Casas I, Holt WV, Yeste M (Ed.). Boar Reproduction. Berlin: Springer. pp. 281-342.

Yeste M. 2015. Recent advances in boar sperm cryopreservation: state of the art and current perspectives. Reprod Domest Anim, 50(suppl 2):71-79.

Yeste M. 2016. Sperm cryopreservation update: cryodamage, markers, and factors affecting the sperm freezability in pigs. Theriogenology, 85:47-64.

Yeste M, Estrada E, Casas I, Bonet S, Rodríguez-Gil JE. 2013a. Good and bad freezability boar ejaculates differ in the integrity of nucleoprotein structure after freeze-thawing but not in ROS levels. Theriogenology, 79:929-939.

Yeste M, Flores E, Estrada E, Bonet S, Rigau T, Rodríguez-Gil JE. 2013b. Reduced glutathione and procaine hydrochloride protect the nucleoprotein structure of boar spermatozoa during freeze-thawing by stabilising disulfide bonds. Reprod Fertil Dev, 25:10361050.

Yeste M, Estrada E, Pinart E, Bonet S, Miró J, Rodríguez-Gil JE. 2014. The improving effect of reduced glutathione on boar sperm cryotolerance is related with the intrinsic ejaculate freezability. Cryobiology, 68:251-261.

Yeste M, Estrada E, Rocha LG, Marín H, Rodríguez-Gil JE, Miró J. 2015. Cryotolerance of stallion spermatozoa is related to ROS production and mitochondrial membrane potential rather than to the integrity of sperm nucleus. Andrology, 3:395-407.

Zeng C, Tang K, He L, Peng W, Ding L, Fang D, Zhang Y. 2014. Effects of glycerol on apoptotic signaling pathways during boar spermatozoa cryopreservation. Cryobiology, 68:395-404.

Zhang XG, Yan GJ, Hong JY, Su ZZ, Yang GS, Li QW, Hu JH. 2015. Effects of bovine serum albumin on boar sperm quality during liquid storage at $17^{\circ} \mathrm{C}$. Reprod Domest Anim, 50:263-269.

Zhang XG, Liu Q, Wang LQ, Yang GS, Hu JH. 2016. Effects of glutathione on sperm quality during liquid storage in boars. Anim Sci $J$, doi: 10.1111/asj.12545.

Zou CX, Yang ZM. 2000. Evaluation on sperm quality of freshly ejaculated boar semen during in vitro storage under different temperatures. Theriogenology, 53:14771488. 